\title{
Visible Cues at Nasi Kandar Eateries Place on Food Safety Practices: The Consumer Perspectives
}

\author{
Muhammad Hafiz Ismail ${ }^{1}$, Norfezah Md Nor ${ }^{2}$, Nurul Liyana Amran ${ }^{3}$ \\ \{pakooor@gmail.com¹, norfezah420@uitm.edu.my², liyanaamran007@gmail.com ${ }^{3}$ \} \\ ${ }^{1,2,3}$ Faculty of Hotel and Tourism Management, Universiti Teknologi MARA, Cawangan Pulau \\ Pinang, Jalan Permatang Pauh, 13500 Seberang Prai, Pulau Pinang, Malaysia
}

\begin{abstract}
Nasi Kandar Eateries is one of the favourable eateries place in Malaysia even though the closure rate of the premises were found higher due to unhygienic handling and dirty environmental. Therefore, this study aimed to identify visible cues that consumers use as indicators in determined the level of food safety of Nasi Kandar eateries. Moreover, the determination of the most influenced visible factors in assessing food safety risk at nasi kandar eateries place from the perspectives of consumer were also carried out. A quantitative research was carried out on 178 respondents through Google Form online survey. The instrument utilized for this research are questionnaire with nonprobability sampling technique and analysed using SPSS adaptation 21 . The findings showed that there was relationship between all factors and there is a solid relationship between premise cleanliness $(r=1.000)$ and personal hygiene $(r=0.772)$. The result also revealed there is a strong relationship among equipment and utensil cleanliness, as shown by the relationship of $r=0.775$. The most impactful data that has a higher change towards food safety practices is premise cleanliness that represented by the value of $\mathrm{R}^{2}=$ 0.326 . Thus, indicated that premise cleanliness is becoming the main factor of consumer's consideration while selecting the Nasi Kandar Eateries.
\end{abstract}

Keywords: Visible Cues, Nasi Kandar eateries place, Food Safety, Consumer's Perception

\section{Introduction}

Food safety was crucial for all food establishment as it related with foodborne illness that correlate to negative consequences of disclosure, depletion of consumer affirmation, and loss of consumer, public health concession and legal costs [1]. However, disorder develop through foods were typical and never-ending issue that resulted in significant amount of dejection and sometimes death [2]. Moreover, food-borne disease was also ascribed to large-scale diversity of bacteria, parasites and viruses that can be found throughout the globe and give disease to human kind extensively.

Malaysia foodservice industry offered various kinds of ethnic based eateries ranging from local Ethnic based restaurant to foreign based ethnic group such as Malay, Chinese, Indian, Punjab, Mamak, Japan, Irish, German, French, and etc. The growing number and size of ethnic restaurant keep increasing from time to time, that resulted boundless selections of restaurant with variousof ideas and characters. One of the most mainstream choices of foodservice outlets in Malaysia was ethnic based eatery of mamak restaurant. When depicted 'mamak', the initial introduction was the Indian Muslims identity. Mamak was a term used in Malaysia to depict an individual from the origin of India to be specifically an individual that is an Indian Muslim [3]. 
The rapid growth of 'nasi kandar' outlet in state has lead people to crave and eat 'nasi kandar' frequently as highlighted by Datuk Dr Ghazali Othman, Director of The State Health Department. Meanwhile, [4] indicated that nasi kandar consumption sequence among consumer in the Klang Valley scored a total of $64.7 \%$ would dine with peers and family while in Penang scored $27.3 \%$ would dine out with family members. Moreover, study factors influencing customers patronizing mamak restaurants a survey in Shah Alam revealed that the consumer often dines 2 to 3 times a week at mamak restaurants with a total of $32 \%$ and $23.7 \%$ for those dines more than 7 times a week [4]

However, most of the nasi kandar's eateries place failed to meet state or violating Health Department hygiene and health standards therefore, under Section 11 of the Food Act 1983 that required them to close their business for two weeks. Based on statistic in [5] a total of 609 cases of food poisoning in Penang had been registered in 2016 compared to the year before with a total of 497 cases, an increasing rate of $22.5 \%$ cases [5]. Food itself can become contaminated with disease-causing bacteria anywhere the food was handled or stored such as in a factory, truck, shop, food outlet and many more.

In curbing this issues, besides of proactive action taken by the local authority and cooperation from the foodservice operators, consumers also can play an important role even it only based on their subjective assessment of the various food safety visible cues found in eating places as potential hazards. Therefore, in understanding towards these visible cues, this study aimed to examine the constructs of food safety cues consumers employed in evaluating the food safety risk of a Mamak Eateries Place.

\section{Literature Review}

\subsection{Food Safety}

Food safety is widely known to be the utmost distress due to its great impact on the health of humankind [6]-[8]. However, for Malaysians take food intently but barely concerned about food safety [9] different than [10] research stipulate that food safety is a worldwide affair. Researcher in [6] stated that food trading has grown worldwide and surely it will affect the food safety practices especially in food production.

Several factors causes to the growing of foodborne illness and among those factors are lack of food safety knowledge and handling ettiques in food safety practices [11], [12]. Lack of knowledge in food safety can relate towards the consumer or food handlers but it proven from the consumer perspective. Whereby, as indicated by [9] consumer edification is perceive as the core of food safety because educated consumers take role as food safety surveyor in their own way. Moreover, [8] predict that an elevation of knowledge level in determining food chains component will lead to refine assurance and continuance of more endurable systems.

\subsection{Credence and Visible Cues}

One of the important credence attributes towards selection of food restaurant is food safety attributes [13]. According to [14] Redmond and Griffith, cue is a sign and reminder of something; directly to be self-explanatory and pre-retentive, it brings to mind knowledge from previous experiences providing a framework for its own interpretation. Thus, in selecting the food restaurant the consumer may only depends on visible cues such as the sanitary condition of an open kitchen, the cleanliness of dishes, the workers' personal hygiene, the cooking time (if visible). Nonetheless, it is impossible for consumers to be certain the safety level of food 
prepared in a closed kitchen, nor it is practical for them to carry a thermometer to measure the food temperature or microbiological test kit to determine the microbial level. In other words, consumers may rely predominantly on the visible cues in judging the level of food safety in the foodservice outlets [15]. Moreover, Visible cues nowadays can be as a tool that can assist consumers in making their decisions carefully as they now are more concern about food safety and nutritional health [16].

\subsection{Nasi Kandar Eateries Place}

'Nasi Kandar' was defined as a simmer white rice array inside a wooden basket and bear on the shoulder using a pole [4]. Nasi Kandar was the main and most favourable dish for Malaysian people especially in Penang, Kuala Lumpur, Selangor, Perak and Perlis with their own unique version of nasi kandar that has mildly-flavoured steamed rice complements by a variation of curry-based meat dishes and vegetables. Nasi Kandar began as food for the coolies, but today it imposed as a treat for fans who cannot get enough of its moreish lusciousness. It is also a Malaysian institution but originated from Indian.

\section{Research Methodology}

This study employed a quantitative approach in collecting and analyzing its data. The questionnaires were then distributed to 178 target respondents in Malaysia through Google Form online survey. Respondents were required to answer all questions in the questionnaire that comprises of nine (9) main sections as followed; Part A: Any Experience or Information Sources of the Nasi Kandar Eateries, Part B: Factors Influencing in Selection of Eateries, Part C: Premise Cleanliness, Part D: Personal Hygiene,Part E: Equipment and Utensil Cleanliness,Part F: Food, Cooking, Display and Served,Part G: Ambient Scent or Odour ,Part H: Food Safety Practices, Part I: Demographic Information. These questionnaires were adopted and adapted from the study of foodservice hygiene factors from consumer perspective [17] as the research and form of survey was competent and comparable with the current study. Closed ended questions were given in Part A and B. While five-point Likert scale ranging from strongly disagree (1) to strongly agree (5) were used in Part C to H. Pilot study was carried out to determine reliability and validity of the questionnaire and upon completion of the pilot study, the survey was updated and improved. SPSS was used to analyze quantitative data which involved descriptive statistics, Pearson correlation and multiple regression analysis.

\section{Findings and Discussions}

\subsection{Visible Cues on Mamak Eateries Selection}

All the variables that has been tested by Cronbach's Alpha for validity and reliability were found in range of 0.782 (good) to 0.942 (excellent) result. While, result revealed that premise cleanliness become main concerned by the customers. Table 1 showed overall result on premises selection based on cue visible. In Table 1, the analysis for factors influencing in selection of eateries yielded a t-value of 1.715 which was not significant at the specified level $(p=0.192)$. Same goes to premise cleanliness yielded a t-value of 8.660 which was not significant at the specified level $(\mathrm{p}=0.004)$. Then, personal hygiene yielded a t-value of 7.137 which was not significant at the specified level $(\mathrm{p}=0.008)$, equipment and utensil cleanliness yielded a t-value of 3.121 which was not significant at the specified level $(\mathrm{p}=0.079)$. Next, 
food, cooking, display and served yielded a t-value of 6.651 which was not specified level $(\mathrm{p}=0.011)$, ambient scent or odour yielded a t-value of 0.355 which was not significant at the specified level $(\mathrm{p}=0.552)$ and lastly food safety practices yielded a t-value of 3.873 which was also not significant at the specified level $(\mathrm{p}=0.051)$.

Table 1. Pearson Correlations Coefficient

\begin{tabular}{|c|c|c|c|c|c|c|c|}
\hline & & $\begin{array}{c}\text { Premise } \\
\text { Cleanliness }\end{array}$ & $\begin{array}{l}\text { Personal } \\
\text { Hygiene }\end{array}$ & $\begin{array}{c}\text { Equipment } \\
\text { Utensil } \\
\text { Cleanliness }\end{array}$ & $\begin{array}{c}\text { Food, } \\
\text { Cooking, } \\
\text { Display } \\
\text { and Served }\end{array}$ & $\begin{array}{c}\text { Ambient } \\
\text { Scent or } \\
\text { Odour }\end{array}$ & $\begin{array}{c}\text { Food } \\
\text { Safety } \\
\text { Practices }\end{array}$ \\
\hline \multirow{4}{*}{$\begin{array}{r}\text { Premise } \\
\text { Cleanliness }\end{array}$} & Pearson & 1 & $.772^{* *}$ & $.755^{* *}$ & $.710^{* * *}$ & $.663^{* *}$ & $.571^{* * *}$ \\
\hline & Correlation & & & & & & \\
\hline & Sig. (2-tailed) & & .000 & .000 & .000 & .000 & .000 \\
\hline & $\mathbf{N}$ & 178 & 178 & 178 & 178 & 178 & 178 \\
\hline \multirow[t]{3}{*}{$\begin{array}{r}\text { Personal } \\
\text { Hygiene }\end{array}$} & $\begin{array}{l}\text { Pearson } \\
\text { Correlation }\end{array}$ & $.772^{* *}$ & 1 & $.821^{* *}$ & $.703^{* *}$ & $.686^{* *}$ & $.496^{* *}$ \\
\hline & Sig. (2-tailed) & .000 & & .000 & .000 & .000 & .000 \\
\hline & $\mathbf{N}$ & 178 & 178 & 178 & 178 & 178 & 178 \\
\hline \multirow{3}{*}{$\begin{array}{r}\text { Equipment } \\
\text { Utensil } \\
\text { Cleanliness }\end{array}$} & $\begin{array}{l}\text { Pearson } \\
\text { Correlation }\end{array}$ & $.755^{* *}$ & $.821^{* *}$ & 1 & $.765^{* *}$ & $.710^{* *}$ & $.488^{* *}$ \\
\hline & Sig. (2-tailed) & .000 & .000 & & .000 & .000 & .000 \\
\hline & $\mathbf{N}$ & 178 & 178 & 178 & 178 & 178 & 178 \\
\hline \multirow{3}{*}{$\begin{array}{r}\text { Food, } \\
\text { Cooking, } \\
\text { Display and } \\
\text { Served }\end{array}$} & $\begin{array}{l}\text { Pearson } \\
\text { Correlation }\end{array}$ & $.710^{* *}$ & $.703^{* *}$ & $.765^{* *}$ & 1 & $.793^{* *}$ & $.542^{* *}$ \\
\hline & Sig. (2-tailed) & .000 & .000 & .000 & & .000 & .000 \\
\hline & $\mathbf{N}$ & 178 & 178 & 178 & 178 & 178 & 178 \\
\hline \multirow{3}{*}{$\begin{array}{r}\text { Ambient } \\
\text { Scent or } \\
\text { Odour }\end{array}$} & $\begin{array}{l}\text { Pearson } \\
\text { Correlation }\end{array}$ & $.663^{* *}$ & $.686^{* *}$ & $.710^{* *}$ & $.793^{* *}$ & 1 & $.615^{* *}$ \\
\hline & Sig. (2-tailed) & .000 & .000 & .000 & .000 & & .000 \\
\hline & $\mathbf{N}$ & 178 & 178 & 178 & 178 & 178 & 178 \\
\hline \multirow[t]{3}{*}{$\begin{array}{r}\text { Food Safety } \\
\text { Practices }\end{array}$} & $\begin{array}{l}\text { Pearson } \\
\text { Correlation }\end{array}$ & $.571^{* *}$ & $.496^{* *}$ & $.488^{* *}$ & $.542^{* * *}$ & $.615^{* *}$ & 1 \\
\hline & Sig. (2-tailed) & .000 & .000 & .000 & .000 & .000 & \\
\hline & $\mathbf{N}$ & 178 & 178 & 178 & 178 & 178 & 178 \\
\hline
\end{tabular}

As indicated by the test conducted in Table 1, there is a strong relationship between premise cleanliness and personal hygiene, where the relationship is $r=1$ and $r=.772$. Next, the outcome appeared there is yet a strong relationship among equipment and utensil cleanliness, which stated the relationship of $r=.775$. The result of relationship of the other three variables, food, cooking, display and served, ambient scent or odour and lastly food safety practices show a strong relationship, where their relationships are $\mathrm{r}=.710, \mathrm{r}=.663$ and $\mathrm{r}=.571$ individually. 


\section{Conclusion}

As a conclusion, this research may give better understanding in influencing awareness towards food safety practices especially at nasi kandar eateries among consumer. The information and result from this research also can be use and advantageous to all parties but mainly consumer who has concern about foodborne illness in food establishment especially at nasi kandar eateries in Malaysia. In future, hopefully it can be useful to the consumer of nasi kandar eateries or other food establishment to be more aware on choosing the proper nasi kandar eateries throughout their whole experience. This research may also help in reducing foodborne illness or food poisoning cases and statistic in Malaysia from getting widespread. As for this moment, precaution and awareness should be vital to consumer because the knowledge has been widely shared as they can avoid any food-borne illness from widely spread.

Acknowledgement. The authors would like to highlight the enormous appreciation offered by Universiti Teknologi MARA Cawangan Pulau Pinang.

\section{References}

[1] A. J. Knight, M. R. Worosz, and E. C. D. Todd, "Serving food safety: Consumer perceptions of food safety at restaurants," Int. J. Contemp. Hosp. Manag., 2007.

[2] M. M. Zain and N. N. Naing, "Sociodemographic characteristics of food handlers and their knowledge, attitude and practice towards food sanitation : A preliminary report," Southeast Asian J. Trop. Med. Public Health, 2002.

[3] A. Shuhaida, M. Ramly, R. Ahmad, and S. N. Ahmadin, "Factors Influencing Customers Patronizing Mamak Restaurants - A Survey in Shah Alam," Second Natl. Educ. Conf. 2003, 2004.

[4] A. R. Abdul Rais, W. M. Wan Abdul Manan, A. R. Shariza, and W. A. Wan Nadiah, "A comparative study of 'nasi kandar' eating patterns among patrons in the klang valley and penang of Malaysia," Int. Food Res. J., 2013.

[5] JKNPP, “Laporan Tahunan 2016," Pulau Pinang, 2016.

[6] K. Mahmood, J. Khalid, H. Kamilah, A. J. Ali, L. Mohammad, and F. Ariffin, "An empirical study of food safety, food handling, and food poisoning awareness among foreign students in Penang, Malaysia," Int. J. Adv. Sci. Eng. Inf. Technol., 2018.

[7] K. G. Grunert, "Food quality and safety: Consumer perception and demand," in European Review of Agricultural Economics, 2005.

[8] A. J. M. Beulens, D. F. Broens, P. Folstar, and G. J. Hofstede, "Food safety and transparency in food chains and networks. Relationships and challenges," Food Control, 2005.

[9] A. Philip, "Food safety in Malaysia," Japan Med. Assoc. J., 2015.

[10] S. P. Oliver, B. M. Jayarao, and R. A. Almeida, "Foodborne pathogens in milk and the dairy farm environment: Food safety and public health implications," Foodborne Pathogens and Disease. 2005.

[11] P. Rozin, C. Fischler, S. Imada, A. Sarubin, and A. Wrzesniewski, "Attitudes to food and the role of food in life in the U.S.A., Japan, Flemish Belgium and France: Possible implications for the diet-health debate," Appetite, 1999.

[12] L. Sharif, M. M. Obaidat, and M.-R. Al-Dalalah, "Food Hygiene Knowledge, Attitudes 
and Practices of the Food Handlers in the Military Hospitals," Food Nutr. Sci., 2013.

[13] R. B. Kim, "Determinants of brand equity for credence goods: Consumers' preference for country origin, perceived value and food safety," Agric. Econ. (Czech Republic), 2012.

[14] E. C. Redmond and C. J. Griffith, "Consumer perceptions of food safety risk, control and responsibility," Appetite, 2004.

[15] S. Henson et al., "Consumer assessment of the safety of restaurants: The role of inspection notices and other information cues," J. Food Saf., 2006.

[16] D. Smith and P. Riethmuller, "Consumer concerns about food safety in Australia and Japan," Int. J. Soc. Econ., 1999.

[17] U. Z. A. Ungku Fatimah, H. C. Boo, M. Sambasivan, and R. Salleh, "Foodservice hygiene factors-The consumer perspective," Int. J. Hosp. Manag., 2011. 